\title{
Brug og misbrug af besættelsestidshistorien
}

\author{
Af Henning Poulsen, professor, dr. phil.
}

,Om brug og misbrug af besattelsestidens historie må det slàs fast, at det på ingen måde kan kaldes misbrug at anlagge en kritisk holdning over for begivenhederne dengang eller for den måde, de er blevet karakteriseret $p a ̊$, i forskningen eller $i$ offentligheden. Men det må vare et krav, at kritikken medtanker krigens vilkär, forholdene, som de var og blev oplevet i samtiden. Man mä lige erindre, at Danmark ikke selv havde valgt at lade sig besatte, og grundlaggende forestillinger om, at Danmark simpelthen kunne have nagtet at have noget med de slemme nazister at gore, vil jeg egentlig ikke kalde misbrug, men regulart fantasteri. Vist var danskerne ikke engle, ogjeg narer stor respekt for dem, der dengang manede til kamp mod nazismen og alle, der stottede den. Men arlig talt, at sidde i sin lune stue tres år efter og lofte den moralske pegefinger mod folk, der er dode og ikke kan forsvare sig, er det ikke lidt for billigt?" sagde professor Henning Poulsen ${ }^{1}$ i sin festforelæsning ved uddelingen af H.O. Lange-Prisen 2002 til Hans Kirchhoff d. 17. september 2002.

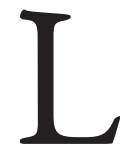

ad mig begynde med at sige, at jeg har kendt dagens prismodtager, Hans Kirchhoff godt i mange år, ja faktisk siden studietiden ${ }^{2}$, så nogen upartisk vurdering af hans indsats i besættelsestidens historie kan jeg nok ikke præstere - selv om det da ikke skal holde mig tilbage fra at prøve på det.

Objektivt kan det konstateres, som det skete i den nyligt udgivne bibliografi om besættelsestiden ${ }^{3}$, at Hans Kirchhoff tegner sig for det største antal af de i alt 7.525 titler, den indeholder [i.e. ca. 8.600 titler, red.]. Han er altså den flittigste forfatter i den uden sammenligning bedst studerede periode af Danmarks historie. At han også er en af dem, der har sat stærkest præg på opfattelsen af den, skal jeg vende tilbage til.

Lad mig først stille det spørgsmål, hvorfor da disse fem år har tiltrukket sig og stadig nyder en så utrolig opmærksomhed, ikke blot i Danmark, men faktisk i hele Europa.
$\mathrm{Ja}$, at det væltede ud med bøger lige efter krigens afslutning, er der ikke noget mærkeligt i. Der var sket meget, og pressen havde været styret eller censureret, så der var en forståelig hunger efter nu endelig at få sandheden frem. Eller måske snarere at få suppleret den sandhed, man allerede mente at kende. For mangel på viden hindrer ikke skråsikre holdninger, og under krigen var det jo, som en polsk historiker har udtrykt det, sådan, at hvad man troede på, ikke afhang af, om den, der udtalte sig, kunne vide noget om det, men kun af, hvem han var. Ven eller fjende. Tænk blot på den illegale presses harmdirrende benægtelse af Goebbels historie om fundet af Katyngravene, hvor tusinder af polske officerer skulle være blevet myrdet af Sovjet, som nu var allieret og altså ven og troværdig.

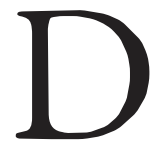
et gælder også opfattelsen af Danmarks historie under den tyske besættelse, at den ikke opstod i et 
tomrum, men udviklede sig af følelsestyngede forestillinger, der med skiftende vægt har fulgt den gennem alle årene. Den dominerende historieopfattelse var den, der tillægges kirkefaderen Augustin, for hvem historiens udvikling var en kamp mellem Gud og djævelen, mellem det gode og det onde. I 1945 vidste man på forhånd, hvem der var heltene - så nogenlunde i hvert fald - og hvem der var skurkene var hævet over al tvivl. Kridtstregen var trukket mellem dem, der holdt med den ene og den anden af krigens parter. At Danmark for en støvet juridisk betragtning ikke havde været med i krigen, så man stort på. Som en nødvendig præmis for retsopgøret var det vedtaget, at Danmark havde været med, på allieret side naturligvis.

En anden opfattelse har besynderligt nok også overlevet årtusindskiftet, nemlig at man ikke vidste rigtig besked, at der var noget, der blev holdt skjult i arkivernes dyb, skumle hemmeligheder, der ikke tålte dagens lys.

For en bredere betragtning er dette $\mathrm{i}$ grunden besynderligt. For sammenligner vi besættelsesårene med et hvilket som helst andet femår af det tyvende århundredes historie, må vi konstatere, at det er ganske unikt, så stort og centralt et kildemateriale der blev publiceret ganske kort efter befrielsen. Lad mig blot nævne de udførlige referater fra det centrale politiske forum, Rigsdagens Samarbejdsudvalg, der allerede blev trykt i 19484, og som giver et indblik i den politiske beslutningsproces, der er uden sidestykke for resten af århundredet. I virkeligheden har kilderne til besættelsens historie været langt mere åbne end til nogen anden samtidshistorisk periode.

For de historikere, deriblandt dagens prismodtager, der i halvtredserne og tredserne begyndte en videnskabelig udforskning af besættelsestidens historie, var målet at nå frem til en mere nuanceret opfattelse af de fem år, og for dem, eller jeg skulle egentlig sige os, var netop mængden af publiceret kildemateriale et incitament til særligt at studere denne periode. Selv valgte jeg at skrive speciale om den tyske politik, fordi der netop var publiceret tre bind gode, beslaglagte dokumenter om den, og husker jeg ikke fejl, tog Kirchhoff af tilsvarende grunde fat på baggrunden for selve besættelsen 9. april $1940^{5}$.

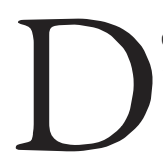
en egentlige udforskning af besættelsestidens historie blev indledt med Jørgen Hæstrups grundlæggende arbejder om modstandsbevægelsen og ført videre i DNH-projektet ${ }^{6}$, som han var leder af, og som bl. a. prismodtageren og jeg selv tog del $i$. Vi arbejdede egentlig i en ret afslappet atmosfære. Pressen refererede udførlig og i reglen loyalt, hvad vi skrev, og selv om det kom som en overraskelse for de fleste, at Kirchhoff i sin disputats i 1979 konstaterede, at folkestrejkerne i august 1943 ikke var fremprovokeret af den tyske værnemagt, og at bruddet 29. august ikke var et resultat af general von Hannekens ønske om at få opløst de danske værn, blev det faktisk taget til efterretning. Det forklares næppe af, at hans argumentation jo var stærk. Sligt generer ikke store ånder. Men begivenhederne var efterhånden kommet så meget på afstand, at samtidens trosvished var afløst af en vis åbenhed. Naturligvis lød der kritik fra visse hold, blandt andet af DNH-projektets såkaldte monopol på arkivadgang. Men det var dog til at leve med.

Tidsfaktoren kan imidlertid ikke forklare den fornyede og anderledes indrettede offentlige interesse for besættelsesårene, der er blusset op i halvfemserne, og 


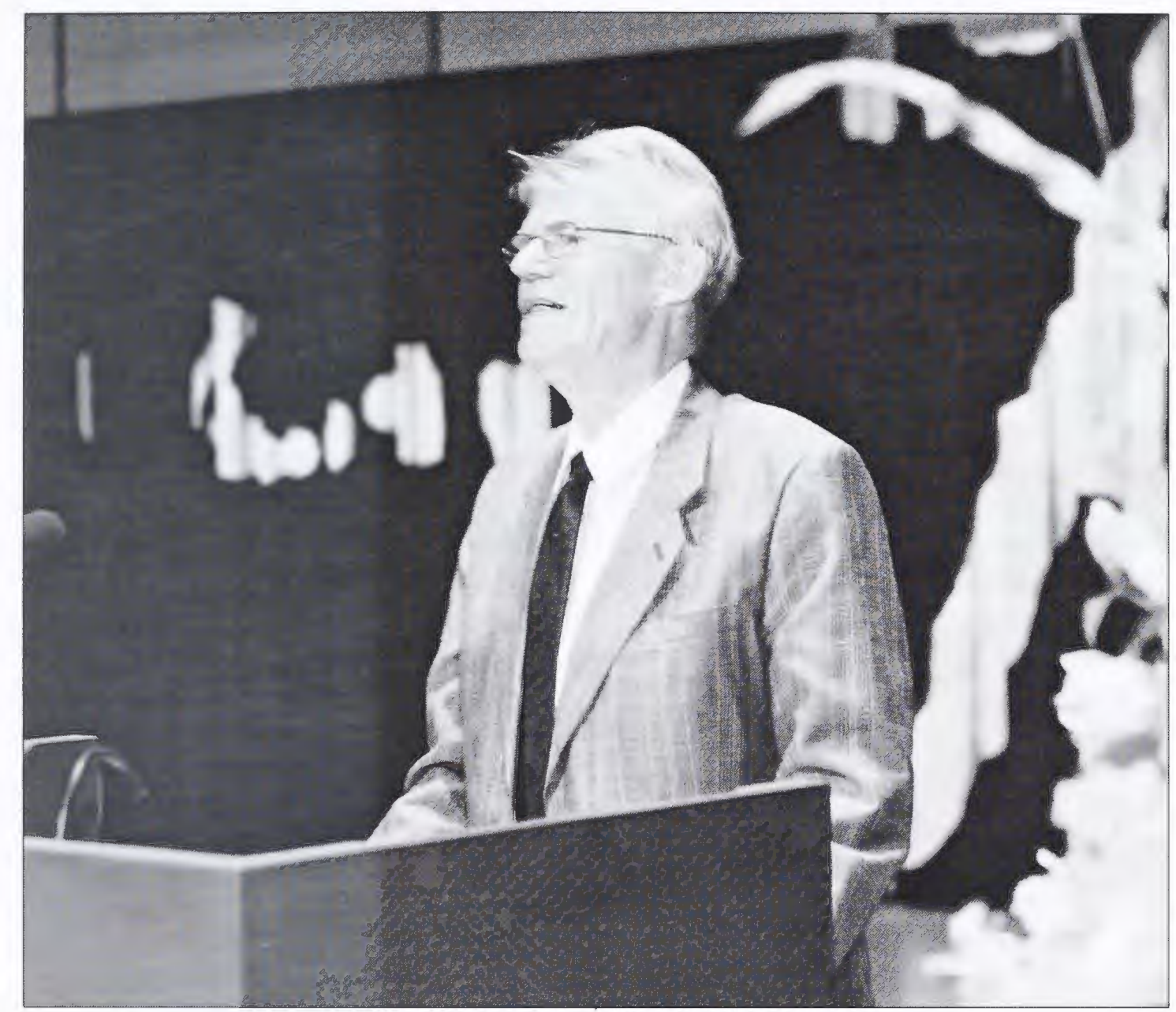

Festforelesning om brug og misbrug af besettelsestidhistorien bleu hold af professor, dr.phil. Henning Poulsen, Arhus (Universitet. (Foto: Det Kongelige Bibliotek).

som i utrolig grad har genoplivet samtidens folelsesladede atmosfære, nymoralismen, som dagens prismodtager har døbt den.

Sådan set skal vi ikke undre os over, at en fortidig hegivenhed er blevet ved med at optage sindene længe efter. Det har vi set for. I sin klassiske skildring af sen-

middelalderen har den hollandske kulturhistoriker, Johan Huizinga peget på, at det trods senere storkrige stadig var korstogstiden, man drømte sig tilbage til ved Europas hoffer. Ikke sådan at forstå, naturligvis, at man i stort tal ilede det kristne

Konstantinopel til undsæetning, da det i 1452 var belejret af de vantro tyrker. I)et var jo en helt anden sag. Men i den fjerne fortid fandt man stadig idealet for ridderlig og kristelig adfærd. Så vi kan ikke engang være sikre på, at en ny storkrig vil gøre det af med legenden om Anden Verdenskrig.

$\mathrm{P}$ arallellen til korstogstiden er klar. Anden Verdenskrig betragtes mindre som en militær og magtpolitisk hegivenhed, mere som en ideologisk konfrontation. I a man for nogle år siden hævede en tysk ubåd i Kattegat, kaldte pressen den ikke en tysk, men en naziubåd, skønt det vel er lidt svært at forstå, hvordan et skib kan have en bestemt ideologisk 
orientering. Men sagen er jo, at Tyskland ikke længere indgår i det nationale fjendebillede. Det opfattes idag ikke som en trussel mod Danmark, men som en god nabo. Det er derfor nu nazismen, der bliver fremhævet, nazismen, der giver Anden Verdenskrig sin korstogskarakter.

At denne tendens blev forstærket $\mathrm{i}$ halvfemserne, har måske forbindelse med, at den kolde krig ebbede så underligt ud, at kommunismen gled ud af det gængse fjendebillede. For sådan ét må man have. Jeg erindrer et intervju med en gruppe fodboldfans, der priste deres stærke sammenhold. De støttede det samme hold, og - tilføjede de - „Vi hader også den samme træner!“ Det er vigtigt. „Kæltringe kan vi på ingen måde undvære“, som Hal Koch skrev i en kritisk kommentar til retsopgøret efter befrielsen.

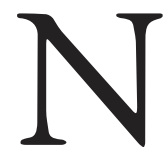

u er det jo lidt verdensfjernt at bekæmpe nazismen 60 år efter. Det er svært at finde mere ondt at sige om Hitler, og de fleste af dem, der spillede en rolle dengang, er forlængst døde. Men her krydses tendensen med en anden, det europæiske kapløb om at vise, at man også i ydmyghed og beskedenhed overgår alle andre.

Da der for nogle år siden kom en lidt besynderlig artikel om manglende dansk lægehjælp til tyske flygtninge ${ }^{7}$, som blev omtalt i pressen, fik jeg et brev fra en forundret tidligere tysk flygtning, som stillede spørgsmålet: „Sig mig, er danskerne blevet grebet af national masochisme?" Det var det ikke helt let at svare nej til.

Tyskerne har i årevis måttet sige undskyld for både det ene og det andet, skønt hovedparten af befolkningen end ikke var født, da krigen endte. Og også nationer, der sådan set befandt sig på den rigtige side, sætter en ære $i$ at indrømme, at deres optræden måske alligevel rummer sorte pletter. Det gælder også Danmark, der jo samarbejdede med besættelsesmagten, som man sagde dengang, eller med Nazityskland, som man vist skal sige i dag. Enhver berøring med den store stygge ulv er naturligvis suspekt, og ud fra den forudsætning er det ikke svært at finde gyselige eksempler frem. Jeg skal ikke gå i detaljer, men blot nævne, at man i pressen har kunnet læse, at en ung historiker nu har afsløret, at det danske landbrug solgte smør og flæsk til dem, man ikke skulle sælge smør og flæsk til, og at Riffelsyndikatet midt under besættelsen minsandten producerede våben til værnemagten. Den sidste nyhed hvis man vil kalde den det - var typisk ledsaget af en gribende reportage om, hvordan nogle journalister $\mathrm{i}$ hemmelighedernes højborg, Rigsarkivet, åbnede en kasse med Erling Foss's hemmelige og kritiske rapporter til London under krigen. Det var næsten synd at fortælle dem, at de kunne have opnået samme resultat på Kommunebiblioteket, da Erling Foss havde udgivet dem i $1946^{\circ}$. Men så ville det jo ikke have taget sig ud som en rigtig afsløring.

$\mathrm{F}$ orargelse er højeste mode, og janteloven gælder i hele dronningeriget. At være kritisk er naturligvis fint. Men hvor forargelsen sætter ind, går forstanden $\mathrm{i}$ stå. Er man nået frem til en moralsk fordømmelse af noget, er man ligesom færdig med det, og glemmer at spørge hvorfor og under hvilke vilkår? Så lærer man ikke noget, opnår højst en hellig vished om, at man sandelig ikke selv ville gøre sådan. Man kan kalde det misbrug af historien. Jeg ville kalde det misbrug af sig selv.

De konkrete eksempler, jeg nævnte, rejser et spørgsmål, der har relevans for alle historikere. Skyldes den uvidenhed, der lyser 
ud af de i virkeligheden gamle nyheder, at vi simpelthen er for dårlige til at formidle vores viden om besættelsesårene? Det må vi jo åbenbart have været. Men generelt synes jeg, den faghistoriske litteratur har været skrevet på en måde og i et sprog, der henvender sig til et bredt publikum, og i hvert fald har ingen kunnet beskylde Hans Kirchhoff for at skrive kedeligt eller uforståeligt.

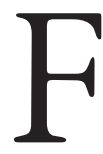

aktisk er jeg sjældent blevet så overrasket, som da Kirchhoff engang fortalte mig, at han skrev langsomt, at den sproglige formulering af det, han skrev, havde taget ham mange dage. For når man læser det, ringer det jo af sted som et kor af mælkeflasker, og de støbeskel mellem den ene og den næste dags arbejde, man skulle forvente at finde, er helt usynlige. Det siger noget om, hvad der er betingelsen for god formidling. Det er tankens konsistens, eller sagt på godt dansk, at man mener noget, og at man har gjort sig klart, hvad det er, man mener. Hvor mange af os har ikke oplevet, at ordene ikke ville som vi, og erkendt, at det skyldtes, at vi ikke havde tænkt meningen rigtigt igennem? Tegnérs ord, at det dunkelt sagte er det dunkelt tænkte, har stadig gyldighed.

Dertil kommer så prismodtagerens misundelsesværdige evne til at gribe og leve sig ind i den enkelte situation og male den op i al sin plastiske fylde. Jeg kan ikke nære mig for at læse et lille afsnit af en artikel, som nok de færreste kender. Den handler om folkestrejkerne i de fynske kystbyer i august 1943 og er kun trykt et så ydmygt sted som i Fynske Årbøger 1971?

Den beskriver bl. a. den kortvarige strejke i Assens, som nok lod sig begrunde i enkelte episoder med matroser fra det tyske skib, der udgjorde garnisonen, men dog først og fremmest skyldtes, at sådan gjorde man i Odense og andre steder. Det vigtigste strejkekrav var, at de tyske marinesoldater skulle være hjemme kl. 21, så ordentlige folk kunne færdes trygt i gaderne. Og sådan har Kirchhoff skildret den afsluttende forhandling:

„Drøftelserne formidledes af politimester Ewald og påbegyndtes lidt over middag i det gamle „Marcussens Hotel“. Sceneriet var ikke uden farve: For bordenden den tyske krigsmarine repræsenteret ved en skibschef og hans to officerer, store mænd med sejre bag sig, men nu med usikkerheden i sindet. Ved venstre langside de tre assenske arbejdere med Marius Jensen - $\mathrm{i}$ daglig tale kun „Røde Marius“ - i spidsen, uimponeret af uniformspragten, sikker på sin ret og indædt besluttet på at sætte soldaterne til vægs. For den anden bordende politimesteren på en af sin karrieres dramatiskehøjdepunkter, ledende forhandlingerne på sit bedste tysk, og ved hans højre side den ene af byens redaktører, den konservative viceborgmester, der synligt nervøs, men med sans for formernes betydning byder på portvin for at bløde sindene op. Og om det nu skyldtes de gode vine på „Marcussens Hotel" eller sagens ubetydelighed, så var tyskerne i hvert fald imødekommende og gik i det hele ind på de danske krav - hvilket nu heller ikke kostede så meget. Oven i købet lykkedes det dem at få landloven forlænget til kl. 22...etcetera".

Jeg skal ikke kommentere teksten eller stille spørgsmål om, hvorfra Kirchhoff har kendt de enkeltes sindstilstand eller vidst, hvad der var højre og venstre side af et langbord. For det er jo ganske ligegyldigt. Lad mig blot bemærke, at fà skønlitterære forfattere kunne have skrevet det bedre - og en ting mere: humor er ikke blot et virkemiddel, men også en erkendelsesform, en forsikring mod selvhøjtidelighed. 


\section{$\mathrm{L}$} ad mig til slut vende tilbage til spørgsmålet om brug og misbrug af det på ingen måde kan kaldes misbrug at anlægge en kritisk holdning over for begivenhederne dengang eller for den måde, de er blevet karakteriseret på, i forskningen eller i offentligheden. Blot må det være et krav, at kritikken medtænker krigens vilkår, forholdene, som de var og blev oplevet i samtiden. Man må lige erindre, at Danmark ikke selv havde valgt at lade sig besætte, og grundlæggende forestillinger om, at Danmark simpelthen kunne have nægtet at have noget med de slemme nazister at gøre, vil jeg egentlig ikke kalde misbrug, men regulært fantasteri. Vist var danskerne ikke engle, og jeg nærer stor respekt for dem, der dengang manede til kamp mod nazismen og alle, der støttede den. Men ærlig talt, at sidde i sin lune stue tres år efter og løfte den moralske pegefinger mod folk, der er døde og ikke kan forsvare sig, er det ikke lidt for billigt?

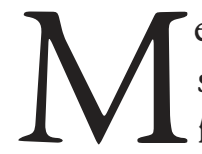
en hvad skal besættelseshistorien så egentlig bruges til? Det er faktisk et godt spørgsmål. I almindelighed kan man sige, at den som anden historie er et led i vores kultur, at den rummer en erfaring, hvilket jo er grunden til, at den skal være sand. Men mere specielt lever interessen for besættelsesårenes historie videre, fordi de er indgået i den nationale mytologi, og de behandles nok i lovlig høj grad som en parentes, som en selvstændig enhed. Det er korrekt, for så vidt som man ikke kan sige, at de ydede noget afgørende bidrag til udviklingen af det danske samfund, der jo i det store hele i 1945 fortsatte, hvor man slap fem år før. Selv bruddet med neutralitetspolitikken, var først og fremmest et produkt af, at krigen havde skabt en ny verdensorden, der gav landet en mulighed for at føre alliancepolitik, det ikke før havde haft. Men studerer man den danske nationalisme, der havde udviklet sig $\mathrm{i}$ de foregående halvandet hundrede år, er besættelsesårene interessante som et kulminationspunkt, hvad mening man så lagde i parolen om det nationale sammenhold, der naturligvis havde dybe furer både på langs og på tværs. Så uden sammenhæng med den generelle udvikling var disse år ikke.

Mest frugtbart kan besættelsestiden bruges som et eksempel på, hvordan det danske samfund med dets mange forgreninger på godt og ondt reagerede på en given udfordring, og det er vel til syvende og sidst spørgsmål af den type, den seriøse interesse for besættelsesårene er bundet op på. Der er tale om splittede reaktioner, som demonstrerer, at opinion ikke er simpel størrelse. Den enkeltes politiske holdning $\mathrm{i}$ almindelighed må beskrives som national, hvad enten han støttede tilpasning eller modstand - eller måske begge dele. Men økonomisk søgte enhver at klare sig igennem, og hvis arbejde for besættelsesmagten var det bedste eller eneste, man kunne få, så tog man det. $\mathrm{Og}$ går vi længere ned, til det personlige plan, var det ikke sjældent, at tyske soldater, man kom i direkte berøring med, blev opfattet som nogle rigtig flinke fyre. Så kompliceret et dyr var mennesket også dengang.

Skal man sammenfatte de i sandhed talrige studier, handler de om spørgsmål, offentligheden allerede havde en mening om, og som faghistorikerne har søgt at korrigere i bredden og i dybden. Hvordan de så bliver brugt af det læsende publikum, har forfatterne intet herredømme over. Måske bruges de til at stille en ægte hunger efter viden, måske til at bekræfte egne fordomme - eller måske blot som underholdning. 
Noter:

Professor i moderne historie ved Aarhus

Universitet 1974-20()().

Cand. mag. i historie og dansk, Kobenhavns Universitet 1960); videnskahelig medarbejder ved Udgiverselskab for I anmarks nyeste Historie 1961-(6); amanuensis ved Aarhus Universitet 1967-74, professor sst. 1974

I.AURII)SEN, John T:: Samarbejde og modstand. I anmark under den tyske besattelse 1940-45. En bibliografi. Det Kongelige Bibliotek: Museum Tusculanums Forlag, 2()()2, 683 ss. (Danish Humanist Texts and Studies, vol. 24).
Se John T. I auridsen, anf. arb., nr. 296a.

"Se afsnit 1.5 „Historieforskning og historieskrivning. Kilde- og metodeproblemer", i: John T. Lauridsen, anf. arb., s. $81 \mathrm{ff}$.

Se John T. I auridsen, anf. arb., nr. 7.49), 7.5() $1-() 3$.

${ }^{8}$ F()SS, Erling: Fra passin til aktin' Modstand. Breve, Microfilmrapporter til I.ondon og Skildring af Frihedsraadets Fremkomst dækkende Perioden April 1940) til Febr. 1944. 1946, $344 \mathrm{~s}$

KIRCHHOFF, Hans: „Bogense, Assens, Fåborg og Kerteminde august 1943. Fire studier i det fynske oprors historie", Fynske Arboger 1971, ss. 139-71.

+ Se John T. Lauridsen, anf. arb., nr. 127.

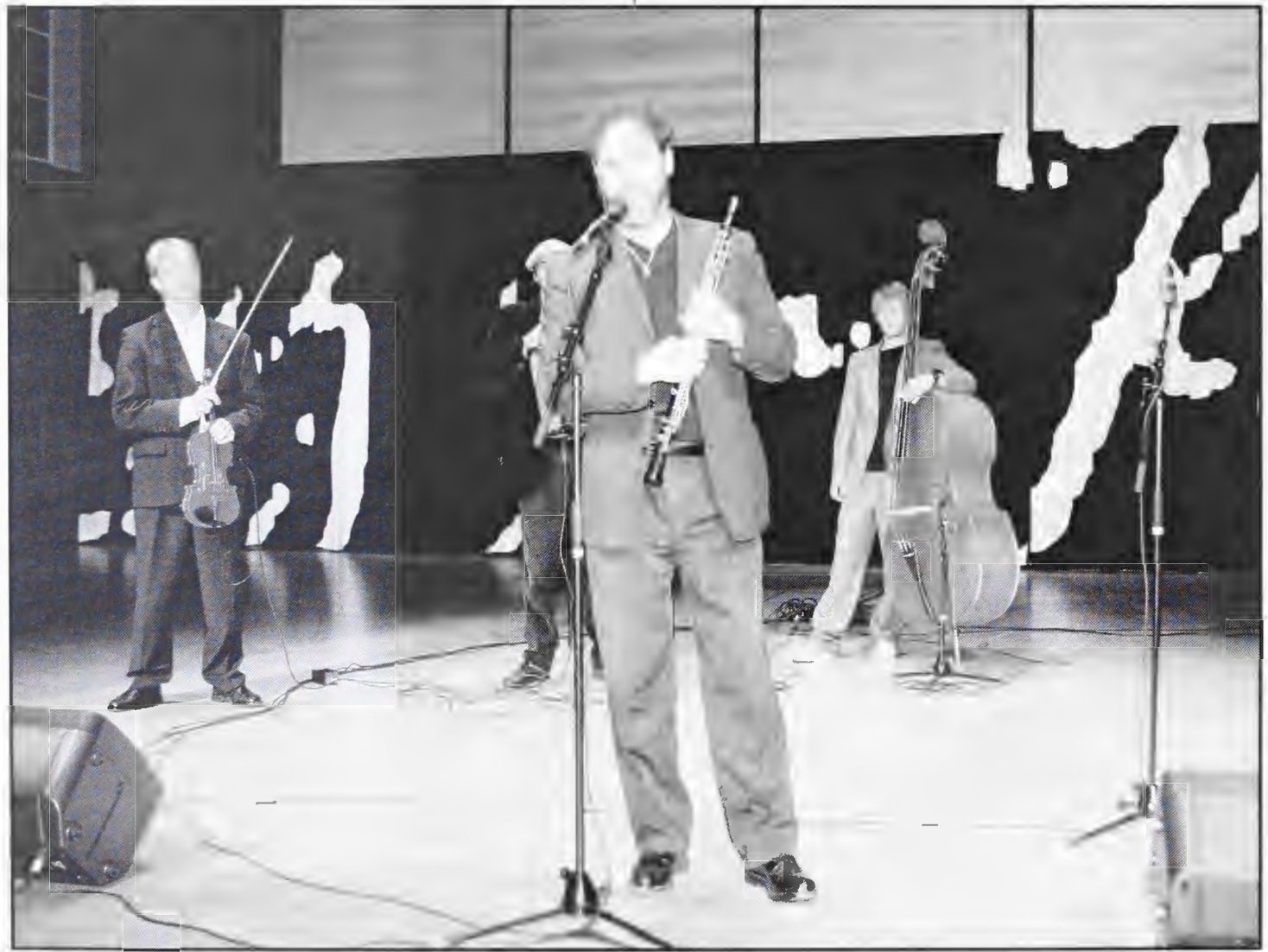

Ciruppen Klezmer Zahav underhold med Klezmermusik ved arets uddeling af H. (). Lange-Prisen. K'lezmermusik er den jodiske folkemusik, som har veret udbredt i Østeuropa fra 160()-tallet og helt op til 2. Verdenskrig. (Foto: Det Kongelige Bibliojek). 